Przegląd Prawa Konstytucyjnego

- -ISSN 2082-1212--------

DOI 10.15804/ppk.2015.01.11

$-\mathrm{Nr} 1(23) / 2015$

\title{
Sprawozdanie
}

\section{Międzynarodowa konferencja naukowo-praktyczna Doświadczenia ustawodawcze Polski i Kazachstanu w zakresie polityki samorządowej i mniejszości narodowych, Warszawa, 9 lipca 2014 r.}

W dniu 9 lipca 2014 r. w Senacie Rzeczpospolitej Polskiej odbyła się konferencja pt. Doświadczenia ustawodawcze Polski i Kazachstanu w zakresie polityki samorzadowej i mniejszości narodowych. Organizatorem Konferencji była Komisja Ustawodawcza i Komisja Administracji Państwowej Senatu RP we współpracy z Ambasadą Kazachstanu i Rady ds. Rozwoju i Współpracy Kazachstańsko-Polskiej Platformy Partnerstwa. Gwarancją najwyższego poziomu Konferencji byli nie tylko jej organizatorzy, zaproszeni prelegenci, ale również prawnicy, w tym wybitni konstytucjonaliści, jak prof. Marek Chmaj, czy przedstawiciele prasy, jak dr Adam Marszałek, oraz parlamentarzyści obu krajów, przedsiębiorcy reprezentujący klastry.

Otwarcia konferencji, oraz słowo wstępne wygłosili: przewodniczący Komisji Ustawodawczej Senatu RP Piotr Zientarski, zastępca przewodniczącego Komisji Samorządu Terytorialnego i Administracji Państwowej Andrzej Matusiewicz, wiceprzewodniczący Mażylisu Sergej Dyachenko, ambasador Republiki Kazachstanu w Polsce JE dr Yerik Utembayev. Prelegenci zwrócili uwagę na fakt, że oba kraje łączą m.in. wspólne historyczne doświadczenia $\mathrm{z}$ okresu rządów socjalistycznych, szybkie tempo wzrostu gospodarczego oraz podobna struktura podziału terytorialnego (16 województw i obwodów, około 2500 gmin). W Koncepcji rozwoju samorządu lokalnego 
Republiki Kazachstanu z listopada 2012 r. to polskie doświadczenia zostały wymienione jako jeden $z$ istotnych wzorów przy jej opracowaniu. Ważnym aspektem rozwoju Kazachstanu, kraju wielonarodowego (140 narodowości i 17 wyznań), jest utrzymanie zgody międzyetnicznej.

Konferencja została podzielona na dwie sesje plenarne. W pierwszej z nich zabrało głos dwóch prelegentów: prof. nadzw. dr hab. Andrzej Bisztyga, rektor Górnośląskiej Wyższej Szkoły Handlowej im. Wojciecha Korfantego w Katowicach. Wystąpienie zatytułowano jako „Terenowa administracja rządowa oraz samorządowa w Republice Kazachstanu. Aspekt Konstytucyjny”. Prelegent zwrócił uwagę na terenową administrację rządową oraz organy samorządowe w Kazachstanie, które są trudne do rozdzielenia, a zwłaszcza w warunkach kazachskich, oraz wskazał determinanty takiego stanu oraz możliwości poprawy obecnego stanu. Zadanie jest to trudne, bowiem brak jest dłuższych doświadczeń konstytucyjnych. Według referenta poza doświadczeniami radzieckimi, jak i przedrewolucyjnymi należy odnieść się do tradycji kazachskich. $Z$ uznaniem należy ocenić adaptacje rozwiązań europejskich. Bez samorządu lokalnego nie można budować społeczeństwa obywatelskiego. Dlatego nie bez znaczenia jest podpisany przez prezydenta w 2006 r. dekret zawierający koncepcję rozwoju społeczeństwa obywatelskiego, który jest formalnym przykładem przywództwa normatywnego. Prelegent zwrócił uwagę, że o ile od początku istniał kształt administracji centralnej, to cały czas z europejskiego punktu widzenia oczekujemy rezultatów. Zwrócił uwagę, że proces kształtowania się samorządu terytorialnego cały czas się rozwija i dopiero nadchodzi czas implementacji. Kierunek reformy jest optymistyczny i godny wsparcia, bowiem wpisuje się w europejską aksjologię. Również przepisy uchwalonej i następnie znowelizowanej Konstytucji wypracowują ciekawe standardy. Przede wszystkim określono zasadę prezydenckiej formy rządu, zasadę jednolitości władzy państwowej, co jest połączone z zasadą unitarności państwa. Powyższe rozwiązania z założenia mają zapobiec tendencjom odśrodkowym. Ostatecznie problemem natury konstytucyjnej jest sama konstrukcja organów: Mazlichaty $-\mathrm{z}$ jednej strony są ciałem przedstawicielskim, z drugiej strony wykonawczym, Akimowie - to również organy wykonawcze, które odpowiadają wobec rządu i prezydenta republiki. Mazlichat posiada zakotwiczenie ustawowe i wykonawcze, kadencja może zostać skrócona przez prezydenta republiki. Ma- 
zlichaty wydają decyzje (reshenija) - poza kwestiami budżetowymi, które mogą być procedowane wyłącznie po uzyskaniu zgody Akima, a kontrolowane są następczo przez sąd.

Drugie wystąpienie panelowe wygłosił mgr Bartosz Mendyk - właściciel kancelarii Ius Europae, doktorant Uniwersytetu Jana Kochanowskiego w Kielcach, pt. „Podstawowe problemy reformy Samorządowej Republiki Kazachstanu i problemy ich rozwiązania na przykładzie doświadczeń Rzeczpospolitej Polskiej”. Referent zwrócił uwagę na praktyczne problemy związane $\mathrm{z}$ funkcjonowaniem samorządu terytorialnego w Kazachstanie. Problemy te wynikają z kilku aspektów. Jednym z ważniejszych jest finansowanie jednostek samorządu terytorialnego. Spora część regionów jest deficytowa i wymaga finansowania z budżetu centralnego. Oznacza to, że realizując postulaty części jurysprudencji polskiej - tj. przyznawanie kompetencji na możliwie niskim poziomie - sprawi, że takie jednostki pozbawione finansowania nie tylko nie będą się rozwijać, ale w ogóle mogą upadać. Wymaga to więc uważnego finansowania i przekazywania kompetencji, tak aby zapewnić zrównoważony rozwój. Kwestią odrębną, na którą zwrócił uwagę prelegent, był podział kompetencji pomiędzy Mozlichaty a Akimów. W przeciągu ostatnich lat tendencja ustawodawcza transferuje większość kompetencji na rzecz Akimów. Za takim rozwiązaniem przemawia operatywność rozwiązania. Przyznanie kompetencji Mozlichatom powodować będzie większą rozwagę, jaką zawsze gwarantują organy kolegialne, ale odbędzie się to oczywiście kosztem czasu. Kwestią cały czas rozwijaną w ustawodawstwie jest dodatkowo monitoring i transparentność budżetu. W ostatnim czasie poświęcono temu sporo uwagi, jednakże nie jest to proces zakończony i wymaga ciągłego naprawiania i wypracowywania coraz to lepszych standardów, opierając się zarówno na europejskich wzorcach, ale i tradycjach kazachskich. Ostatnie poruszone zagadnienie dotyczyło strategii rozwoju kraju. Wypracowane dokumenty nie zawsze są kompatybilne ze strategią Kazachstan 2050. Władze Kazachstanu wybierają, na ile pragną zrównoważonego rozwoju kraju, a na ile rozwoju wielkich ośrodków miejskich mających być kołem zamachowym dla całego regionu. Przykład Polski wskazuje problemy z tym związane, zwłaszcza że rezultaty są bardzo zróżnicowane.

Zwieńczeniem wystąpień była obszerna dyskusja, w ramach której wystąpiło 6 dyskutantów. Pierwszym z nich był Eugeniusz Grzeszczak, marsza- 
łek Sejmu; deputowani do Mażylisu Selikszan Kanajew, a następnie Nurłan Żałyzbekow; pan senator Andrzej Matusiewicz - zastępca Senackiej Komisji Samorządu Terytorialnego i Administracji Państwowej; Krzysztof Janik były minister spraw wewnętrznych i administracji; Tomasz Jakubiec - dyrektor Departamentu Rozwoju Miasta Łodzi. Dyskusję zamknął Krzysztof Krystowski, który reprezentował Związek Klastrów Polskich.

Moderatorem drugiego panelu był JE dr Yerik Utembaev, a sekretarzem mgr B. Mendyk. Pierwsze wystąpienie panelowe wygłosił prof. Andrzej Wierzbicki reprezentujący Instytut Nauk Politycznych Uniwersytetu Warszawskiego. Zwrócił on uwagę na zmiany w zakresie polietniczności. To rodzi zagrożenie separatyzmem. Kazachstański model porozumienia międzyetnicznego czerpie nie tylko z zagranicznych standardów, ale i własnych doświadczeń. Model kazachstański odnotował sukces ze względu na zamieszkałą ludność (tzw. laboratorium etniczne; zsyłano tam przedstawicieli wielu narodowości, bowiem Kazachowie dobrze odnosili się do nowych ludzi), politykę władz, w tym prezydenta, który był postawiony pomiędzy nacjonalizmem kazachskim a silnym nacjonalizmem mniejszości rosyjskiej z drugiej strony. Odwołania do niej znajdują się w wielu dokumentach, w tym doktrynie jedności narodowej.

Drugie wystąpienie wygłosiła Agnieszka Słomian na temat Zgromadzenia Narodu Kazachstanu. Według prelegentki Polska mogłaby czerpać dobre praktyki związane z doświadczeniami Zgromadzenia Narodu Kazachstanu. Organ ten liczy 382 członków. Przewodniczącym organu jest prezydent Republiki Kazachstanu, zastępuje go 2 zastępców (w 2009 r. zastępcą był Polak Antoni Święcicki). Najwyższym organem wewnętrznym jest sesja zgromadzenia, która wybiera 9 deputowanych do Mażylisu. Ci z kolei reprezentują narody Kazachstanu. Zgromadzenie Narodu Kazachstanu reprezentuje też interesy mniejszości kulturowych. Rada pracuje pomiędzy sesjami. Centralnym miejscem współpracy pomiędzy krajami stanowią Domy Przyjaźni, które mają być zapleczem eksperckim oraz animować życie w regionach.

W dyskusji głos zabrał Anatol Makowski - deputowany przedstawiciel Mażylisu. Z pochodzenia Polak, jednakże w parlamencie nie reprezentuje żadnej mniejszości. Następnym dyskutantem był ambasador Władysław Sokołowski. Po nim głos zabrał poseł Ryszard Galla reprezentujący mniejszość 
niemiecką w polskim parlamencie. Ostatnim rozmówcą został Paweł Kowal, który zwrócił uwagę na nowoczesną dyplomację.

Międzynarodową Konferencję Naukową Doświadczenia ustawodawcze Polski i Kazachstanu w zakresie polityki samorzadowej i mniejszości narodowych podsumował senator Piotr Zientarski oraz p. Siergiej Diaczenko.

Uczestnicy podkreślali wysoki stopień legislacji Republiki Kazachstanu związany z faktem, że kraj ten jest członkiem Komisji Weneckiej. Nie bez znaczenia jest też fakt organizacji Forum Astańskiego, w którym biorą udział specjaliści z całego świata. Konferencja w Senacie inspiruje nie tylko stronę kazachską, ale i polską, bowiem Kazachstan ma dużo większe doświadczenia związane z mniejszościami narodowymi niż Rzeczpospolita Polska.

Pewnym wspólnym problemem jest istnienie tzw. monomiast, a więc ośrodków, zazwyczaj postindustrialnych, w których całe miasto uzależnione jest (było) tylko od jednego, wielkiego zakładu przemysłowego. Miasto Łódź posiada tutaj już swoje doświadczenia w zakresie rekultywacji tych terenów i wypracowania nowego modus operandi funkcjonowania miasta.

Bartosz Mendyk Kancelaria Ius Europae 